\title{
MENINGKATKAN MINAT BELAJAR SISWA MELALUI METODE RESITASI PADA MATA PELAJARAN ILMU PENGETAHUAN ALAM DI MADRASAH IBTIDAIYAH SWASTA RAUDHATUL MUJAWWIDIN KECAMATAN RIMBO BUJANG KABUPATEN TEBO
}

\author{
Mulyati \\ Institut Agama Islam Yasni Bungo \\ e-mail:vmulyati44@gmail.com \\ Mona Novita \\ Institut Agama Islam Yasni Bungo \\ e-mail: monanovita.staiyasni@gmail.com
}

\begin{abstract}
The background of this study is the low interest in learning MIS grade IV students Raudhatul Mujawwidin on science subjects. This study aims to increase the learning interest of MIS fourth grade students Raudhatul Mujawwidin on science subjects. The type of research used is Classroom Action Research (CAR) with Kemmis and Taggart models. Data collection techniques used are observation, interviews, and documentation. The data analysis technique uses qualitative and quantitative data analysis techniques. The results showed that the use of recitation methods could increase students' interest in learning in science learning in class IV of the MIS Raudhatul Mujawwidin. Students' interest in learning has met the indicator of research success, which is $75 \%$ for each indicator of learning interest. The percentage of students' learning interest in the pre cycle was $47.17 \%$. In the first cycle of $62.20 \%$, and in the second cycle reached $79.24 \%$. Based on the results of data analysis, the application of recitation methods to natural science subjects can increase the interest in learning for fourth grade students of MIS, Raudhatul Mujawwidin. The increase in learning interest is quite significant seen in the indicators of students' happy feelings towards learning, namely $59.67 \%$ in the pre-cycle, $68.93 \%$ in the first cycle, and $83.28 \%$ in the second cycle.
\end{abstract}

Keywords: Recitation Method, Interest in Learning, Science Subjects.

\begin{abstract}
Abstrak
Latar belakang penelitian ini adalah rendahnya minat belajar siswa kelas IV MIS Raudhatul Mujawwidin pada mata pelajaran IPA. Penelitian ini bertujuan untuk meningkatkan minat belajar siswa kelas IV MIS Raudhatul Mujawwidin pada mata pelajaran IPA. Jenis penelitian yang digunakan adalah Penelitian Tindakan Kelas (PTK) dengan model Kemmis dan Taggart. Teknik pengumpulan data yang
\end{abstract}

Nur El-Islam, Volume 6, Nomor 1, April 2019 
digunakan yaitu observasi, wawancara, dan dokumentasi. Teknik analisis data menggunakan teknik analisis data kualitatif dan kuantitatif. Hasil penelitian menunjukkan bahwa penggunaan metode resitasi dapat meningkatkan minat belajar siswa pada pembelajaran IPA di kelas IV MIS Raudhatul Mujawwidin. Minat belajar siswa telah memenuhi indikator keberhasilan penelitian yaitu $75 \%$ pada masingmasing indikator minat belajar. Persentase minat belajar siswa pada pra siklus adalah 47,17\%. Pada siklus I sebesar 62,20\%, dan pada siklus II mencapai 79,24\%. Berdasarkan hasil analisis data, maka penerapan metode resitasi pada mata pelajaran IPA dapat meningkatkan minat belajar siswa kelas IV MIS Raudhatul Mujawwidin. Peningkatan minat belajar yang cukup signifikan terlihat pada indikator perasaan senang siswa terhadap pembelajaran, yaitu 59,67\% pada pra siklus, 68,93\% pada siklus I, dan $83,28 \%$ pada siklus II.

Kata Kunci: Metode Resitasi, Minat Belajar, Mata Pelajaran IPA.

\section{A. PENDAHULUAN}

\section{Latar Belakang Masalah}

Ilmu Pengetahuan Alam (IPA) merupakan cara mencari tahu tentang alam secara sistematis, berisi penguasaan kumpulan pengetahuan berupa fakta, konsep, prinsip, proses penemuan, digunakan dalam kehidupan sehari-hari untuk memenuhi kebutuhan hidup manusia melalui pemecahan masalah yang dapat diidentifikasikan. ${ }^{1}$ Jadi, pembelajaran IPA di SD/MI menekankan pemberian pengalaman belajar secara langsung dengan mengembangkan keterampilan proses dan sikap ilmiah. Pembelajaran IPA perlu diajarkan dengan cara tepat dan berorientasi pada siswa. Keaktifan siswa dan keterampilan guru diperlukan dalam kegiatan belajar mengajar agar pembelajaran menjadi efektif. Semakin tinggi aktivitas siswa di kelas menandakan tingginya minat siswa tehadap proses pembelajaran yang dilakukan. Hal ini sesuai dengan Peraturan Pemerintah Nomor 19 Tahun 2005 Bab IV ayat 1 yang menyebutkan bahwa,

"Standar proses pembelajaran pada setiap satuan pendidikan diselenggarakan secara interaksi, inspiratif, menyenangkan, menantang, memotivasi anak didik untuk berpartisipasi aktif

${ }^{1}$ Permendiknas RI No. 22 Tahun 2006 tentang Standar Isi Satuan Pendidikan Dasar Menengah. https://www.scribd.com/mobile/doc/48620155/lampiran-permendikasnomor-22-tahun-2006tentang-standar-isi-lampiran-SD-MI. diakses tanggal 28 April 2017 
serta memberikan ruang yang cukup bagi prakarsa dan kemandirian sesuai dengan bakat, minat, dan perkembangan fisik serta psikologi anak didik". ${ }^{2}$

Kenyataan yang terjadi di kelas IV Madrasah Ibtidaiyah Swasta (MIS) Raudhatul Mujawwidin menunjukkan bahwa minat siswa dalam pembelajaran IPA masih sangat rendah. Berdasarkan hasil pengamatan dalam proses pembelajaran pada tanggal 18 Juli 2018, rata-rata minat belajar siswa hanya $47.17 \%$ atau dalam kategori sangat kurang. Hal-hal yang menjadi penyebab rendahnya minat belajar siswa adalah karena pembelajaran IPA kelas IV ini berorientasi pada guru (teacher centered approach), didominasi dengan penggunaan metode ceramah, serta kurang memberikan pengalaman yang nyata terhadap siswa.

Permasalahan tersebut harus segera diatasi mengingat pembelajaran IPA bukan hanya penguasaan kumpulan pengetahuan yang berupa fakta-fakta, konsep-konsep, atau prinsip-prinsip saja, tetapi juga merupakan suatu proses penemuan serta dapat menjadi wahana bagi peserta didik untuk mempelajari diri sendiri, alam sekitar, serta prospek pengembangan lebih lanjut dalam penerapannya di kehidupan sehari-hari. ${ }^{3}$ Selain itu, apabila permasalahan tersebut terus dibiarkan, maka akan mempengaruhi kualitas belajar siswa.

Salah satu alternatif untuk meningkatkan minat belajar siswa adalah dengan menerapkan metode pembelajaran resitasi. Penerapan metode resitasi ini dapat merangsang siswa untuk belajar lebih aktif, baik secara perorangan maupun kelompok, menumbuhkan kebiasaan untuk belajar mencari dan menemukan, mengembangkan keberanian dan tanggung jawab terhadap diri sendiri dan memungkinkan untuk memperoleh hasil yang permanen. ${ }^{4}$

2 Trianto, Desain Pengembangan Pembelajaran Tematik Bagi Anak Usia Dini TK/RA \& Anak Kelas Awal SD/MI (Jakarta: Kencana, 2011), h. 139

${ }^{3}$ Isriani Hardini dan Dewi Puspitasari, Strategi Pembelajaran Terpadu: Teori, Konsep, \& Implementasi (Yogyakarta: Familia, 2012), h. 149

${ }^{4}$ Abdul Majid, Strategi Pembelajaran (Bandung: Remaja Rosdakarya, 2014), cet. 3, h. 208 


\section{Identifikasi Masalah}

Berdasarkan latar belakang masalah yang dikemukakan, maka dapat diidentifikasi beberapa masalah dalam pembelajaran IPA, yaitu:

a. Pembelajaran berorientasi pada guru;

b. Kurang memberikan pengalaman yang nyata terhadap siswa; dan

c. Metode pembelajaran belum bervariasi;

d. Siswa kurang berminat terhadap pembelajaran IPA.

\section{Teori/Kajian}

\section{a. Metode resitasi (penugasan)}

Merupakan metode penyajian bahan pelajaran dimana guru memberikan tugas tertentu agar siswa dapat melakukan kegiatan belajar ${ }^{5}$. Metode resitasi ini merangsang siswa untuk belajar lebih aktif, baik secara perorangan maupun kelompok, menumbuhkan kebiasaan untuk belajar mencari dan menemukan, mengembangkan keberanian dan tanggung jawab terhadap diri sendiri dan memungkinkan untuk memperoleh hasil yang permanen ${ }^{6}$. Langkahlangkah penerapan metode resitasi menurut Djamarah dan Zain adalah sebagai berikut:

\section{1) Fase Pemberian Tugas}

Pada fase ini, guru memberikan tugas kepada peserta didik. Tugas yang diberikan hendaknya mempertimbangkan: a) Tujuan yang akan dicapai; b) Jenis tugas yang jelas dan tepat sehingga anak mengerti apa yang ditugaskan tersebut; c) Sesuai dengan kemampuan siswa; d) Ada petunjuk atau sumber yang dapat membantu pekerjaan siswa; e) Tersedianya waktu yang cukup untuk siswa mengerjakan tugas tersebut.

2) Fase Pelaksanaan Tugas

Pada saat pelaksanaan tugas, siswa hendaknya: a) Diberikan bimbingan atau pengawasan oleh guru; b) Diberikan dorongan sehingga anak mau bekerja; c) Diusahakan atau dikerjakan oleh

${ }^{5}$ Jumanta Hamdayama, Metodologi Pengajaran (Jakarta: PT Bumi aksara, 2016), h. 17

${ }^{6}$ Ibid., h. 209 
siswa sendiri, tidak menyuruh orang lain; d) Dianjurkan siswa mencatat hasil-hasil yang ia peroleh dengan baik dan sistematik.

\section{3) Fase Mempertanggungjawabkan Tugas}

Fase inilah yang disebut resitasi. Hal yang harus dikerjakan pada fase ini adalah: a) Laporan siswa baik lisan atau tertulis dari apa yang telah dikerjakannya; b) Ada tanya jawab atau diskusi kelas; c) Penilaian hasil pekerjaan siswa baik dengan tes maupun nontes atau cara lainnya. ${ }^{7}$

Menurut Jamil, kelebihan metode pembelajaran resitasi adalah sebagai berikut: 1) Merangsang siswa dalam melakukan aktivitas belajar individu dan kelompok; 2) Meningkatkan kemandirian, tanggung jawab, disiplin, kreativitas, dan kerja sama siswa di luar pengawasan guru; 3) Meningkatkan pemahaman siswa akan materi karena siswa belajar menemukan sendiri materi melalui tugas yang diberikan; 4) Tugas yang diberikan adalah masalah nyata yang dihubungkan dengan materi pelajaran sehingga siswa memahami makna dan manfaat materi yang dipelajari. ${ }^{8}$

\section{b. Minat Belajar Siswa}

Minat adalah suatu rasa ketertarikan yang timbul dari diri sendiri terhadap sesuatu setelah melihat sesuatu yang ada di luar dirinya ${ }^{9}$. Minat (interest) dapat juga diartikan sebagai kecenderungan dan kegairahan yang tinggi atau keinginan yang besar terhadap sesuatu. ${ }^{10}$ Menurut Slameto, siswa yang memiliki minat terhadap subyek tertentu memiliki ciri-ciri: 1) Memberi perhatian lebih pada kegiatan yang diamati; 2) Aktif mengikuti kegiatan atau hal yang diminati; 3) Menunjukkan rasa senang ketika melakukan kegiatan atau

${ }^{7}$ Syaiful Bahri Djamarah dan Aswan Zain, Strategi Belajar Mengajar, (Jakarta: Rineka Cipta, 2013), h. 86

${ }^{8}$ Suprihatiningrum, Strategi Pembelajaran, h. 292-293

${ }^{9}$ H. Cholil dan Sugeng Kurniawan, Psikologi Pendidikan; Telaah Teoritik dan Praktik, (Surabaya: IAIN Sunan Ampel Press, 2011), h. 48

${ }^{10}$ Baharuddin dan Esa Nur Wahyuni, Teori Belajar \& Pembelajaran (Yogyakarta, Ar-Ruzz Media, 2015), h. 29 
hal yang diminati. ${ }^{11}$ Senada dengan pendapat Slameto, Syaiful Bahri Djamarah menyatakan bahwa siswa yang berminat dalam kegiatan belajar mempunyai ciri-ciri: 1) Pernyataan yang menunjukkan bahwa siswa lebih menyukai sesuatu daripada yang lainnya; 2) Partisipasi aktif dalam suatu kegiatan; 3) Perhatian yang lebih besar terhadap sesuatu yang diminati tanpa menghiraukan yang lain. ${ }^{12}$

Berdasarkan beberapa indikator yang telah dikemukakan di atas, penelitian ini menggunakan indikator minat sebagai berikut:

\section{1) Perhatian Siswa dalam Kegiatan Belajar Mengajar}

Adapun indikatornya meliputi: a) Fokus memperhatikan penjelasan guru dalam pembelajaran; b) Mencatat penjelasan guru; c) Membaca materi ajar; d) Serius dalam pelaksanaan tugas; e) Bersemangat mengerjakan tugas; f) Tekun dan tidak mudah putus asa dalam menyelesaikan tugas yang diberikan.

2) Partisipasi Aktif Siswa dalam Kegiatan Belajar Mengajar

Adapun indikatornya meliputi: a) Menjawab pertanyaan guru; b) Bertanya kepada guru; c) Mengemukakan pendapat; d) Aktif melakukan pengamatan; e) Aktif mempresentasikan hasil pengamatannya; f) Menanggapi presentasi teman; g) Diskusi dengan anggota kelompoknya; h) Menyimpulkan hasil pembelajaran.

3) Perasaan Senang terhadap Kegiatan Belajar Mengajar

Adapun indikatornya meliputi: a) Masuk kelas tepat waktu; b) Membawa alat tulis dan buku; c) Mempunyai catatan materi ajar yang lengkap; d) Menyelesaikan tugas tepat waktu; e) Bertanggungjawab terhadap tugas; e) Tidak gelisah dalam belajar; f) Tidak mudah bosan dan menyerah dalam menyelesaikan tugas; g) Bersikap ceria.

${ }^{11}$ Nur Khalida Prettiana, "Peningkatan Minat Belajar IPA Melalui Model Pembelajaran Kooperatif Tipe STAD (Student Teams Achievement Divisions) pada Siswa Kelas V SD N 1 Sedayu Bantul” (Skripsi, FIP Universitas Negeri Yogyakarta, 2016), h. 12

${ }^{12}$ Ferry Sulistiyono, "Peningkatan Minat Belajar Siswa Terhadap Pembelajaran Tematik Kelas I Melalui Metode Story Telling di SD N Gembongan Sentolo Kulon Progo” (Skripsi, FIP Universitas Negeri Yogyakarta, 2014), h.11 


\section{Tujuan Penelitian}

Tujuan dilakukannya PTK ini adalah untuk:

a. Mengetahui peningkatan minat belajar siswa pada mata pelajaran IPA dengan menggunakan metode resitasi di kelas IV MIS Raudhatul Mujawwidin.

b. Mengetahui indikator minat belajar siswa pada mata pelajaran IPA melalui penerapan metode resitasi yang mengalami peningkatan yang cukup signifikan.

\section{Metodologi Penelitian}

\section{Metodologi Penelitian}

Jenis penelitian ini adalah Penelitian Tindakan Kelas (PTK) yang dilakukan secara kolaboratif dengan guru kelas IV MIS Raudhatul Mujawwidin. Subjek penelitian ini adalah siswa kelas IV MIS Raudhatul Mujawwidin yang berjumlah 36 siswa, terdiri atas 24 siswa laki-laki dan 12 siswa perempuan. Prosedur pelaksanaan PTK ini sesuai dengan prosedur yang telah dikemukakan oleh Kemmis dan Mc Taggart yang meliputi kegiatan perencanaan, tindakan dan pengamatan, refleksi, serta perencanaan ulang.

Sumber data primer dalam penelitian ini adalah siswa dan guru. Data yang didapat dari siswa kelas IV MIS Raudhatul Mujawwidin ini yaitu data mengenai minat siswa dalam pembelajaran yang didapat dengan menggunakan lembaran observasi. Sedangkan data yang didapat dari guru kelas IV MIS Raudhatul Mujawwidin ini yaitu data mengenai minat siswa dalam pembelajaran yang didapat dengan menggunakan lembaran wawancara. Data sekunder dalam penelitian ini yaitu: a) Lembaran observasi; b) Absen siswa; c) Nilai rapor/Ulangan harian; d) Dokumentasi.

Teknik pengumpulan data yang dilakukan dalam penelitian ini adalah sebagai berikut:

\section{a. Teknik Observasi}

Merupakan teknik yang dipergunakan untuk mengetahui minat belajar siswa dengan penerapan metode pembelajaran resitasi dalam kegiatan belajar mengajar. Observasi dilakukan pada setiap pelaksanaan pembelajaran IPA di kelas. 
b. Teknik wawancara

Dilaksanakan untuk mengetahui minat siswa dalam kegiatan belajar mengajar. Wawancara dilakukan pada awal dan akhir penelitian.

c. Teknik Dokumentasi

Dipergunakan untuk mengetahui Kriteria Ketuntasan Minimal (KKM) mata pelajaran IPA di MIS Raudhatul Mujawwidin, silabus pembelajaran, jumlah siswa, serta aktivitas siswa pada saat penelitian berlangsung.

Sedangkan instrumen yang dipergunakan dalam pengumpulan data penelitian ini yaitu:

\section{a. Lembaran Observasi}

Digunakan untuk mendukung kegiatan pengumpulan data penelitian dengan kisi-kisi sebagai berikut:

\section{Tabel 1 Kisi-Kisi Observasi Minat Belajar Siswa}

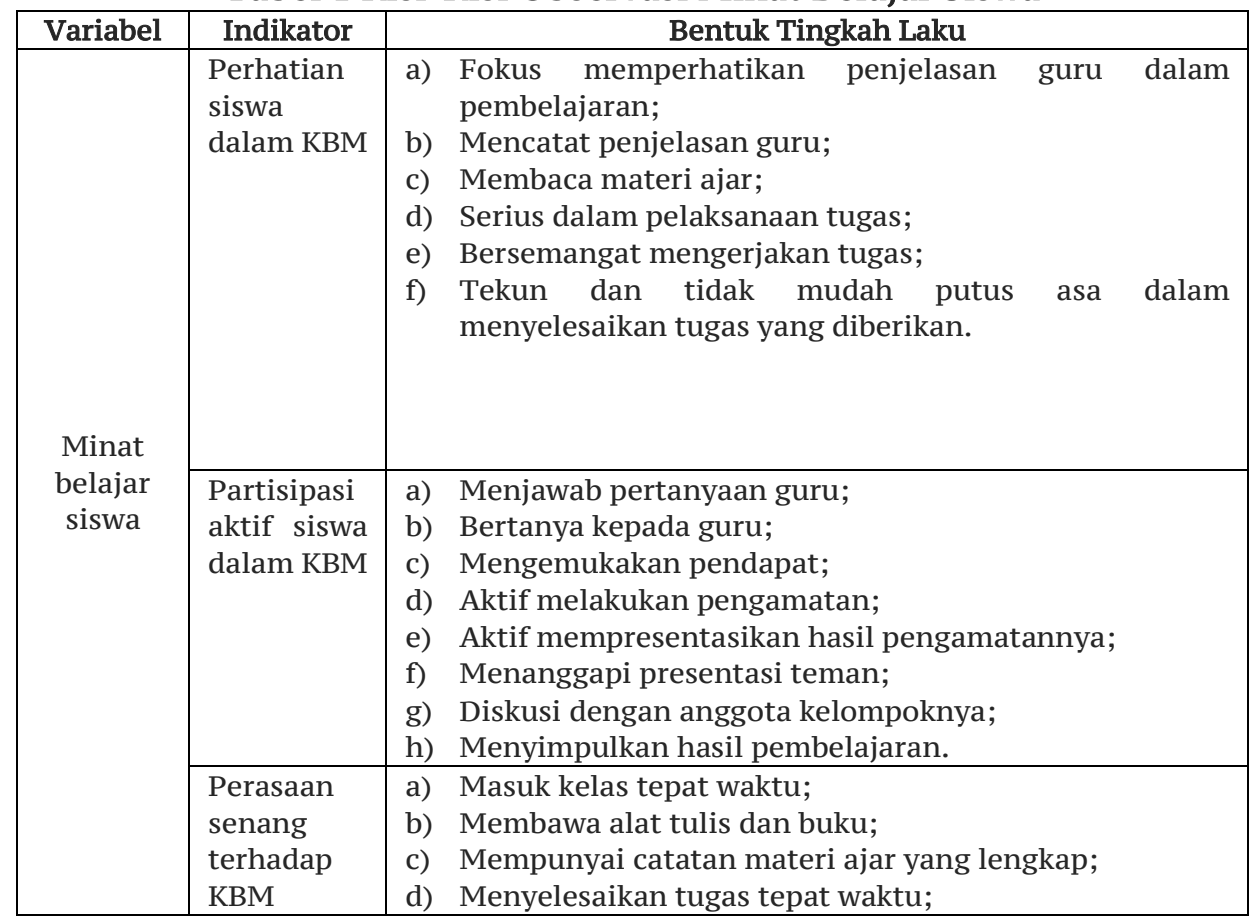


Mulyati, Mona Novita

\begin{tabular}{|l|l|lll|}
\hline Variabel & Indikator & \multicolumn{3}{|c|}{ Bentuk Tingkah Laku } \\
\hline & & e) Bertanggungjawab terhadap tugas; & \\
& & f) Tidak gelisah dalam belajar; & \\
& & g) Tidak mudah bosan dan menyerah dalam \\
& & menyelesaikan tugas; & \\
& & h) Bersikap ceria. & \\
\hline
\end{tabular}

b. Lembaran Wawancara, meliputi hal-hal sebagai berikut: 1) Meminta pendapat guru tentang pelaksanaan pembelajaran di kelas, antara lain mengungkap minat siswa dalam pembelajaran, kelebihan, kekurangan, dan permasalahan lain yang berhubungan dengan pembelajaran di kelas; 2) Meminta pendapat guru mengenai efektivitas penerapan metode resitasi dalam pembelajaran di kelas; 3) Mendiskusikan hal-hal yang telah dikemukakan baik guru maupun peneliti untuk disepakati hal-hal yang perlu dilakukan pada langkah selanjutnya.

c. Dokumentasi, dilakukan untuk mengetahui KKM mata pelajaran IPA, silabus, jumlah siswa, serta foto-foto pada saat siswa melakukan proses pembelajaran dengan menggunakan metode resitasi.

Teknik analisis data yang digunakan dalam penelitian ini adalah analisis data kualitatif dan kuantitatif. Analisis data kualitatif terdiri atas 3 komponen kegiatan yang saling terkait satu sama lain, yaitu reduksi data (data reduction), penyajian data (display data), dan penarikan kesimpulan atau verifikasi. Kriteria keberhasilan penelitian tentang minat belajar siswa ditetapkan sebagai berikut:

Tabel 2 Kriteria Hasil Penelitian ${ }^{13}$

\begin{tabular}{|c|c|}
\hline Rentang Nilai & Kriteria \\
\hline $0 \% \leqslant N R \leqslant 60 \%$ & Sangat Kurang \\
\hline $60 \% \leqslant N R \leqslant 70 \%$ & Kurang \\
\hline $70 \% \leqslant N R \leqslant 80 \%$ & Cukup \\
\hline $80 \% \leqslant N R \leqslant 90 \%$ & Baik \\
\hline $90 \% \leqslant N R \leqslant 100 \%$ & Sangat Baik \\
\hline
\end{tabular}

${ }^{13}$ R. Hidayah, “Bab III Metode Penelitian.” Repo.iain-tulungagung.ac.id. diakses pada tanggal 5 Oktober 2018 
Kriteria hasil penelitian tersebut diperoleh melalui:

$$
\text { persentase }=\frac{\text { skor diperoleh }}{\text { skor maksimal }} \times 100^{14}
$$

Guna memperoleh instrumen penelitian yang mempunyai validitas baik, maka dalam proses penyusunan instrumen peneliti menggunakan teknik triangulasi sumber. Triangulasi sumber digunakan dengan mendapatkan informasi dari siswa maupun guru yang didapatkan melalui teknik observasi, wawancara, dan dokumentasi.

\section{Hipotesis Penelitian}

Penelitian ini dikatakan berhasil apabila minat belajar siswa kelas IV MIS Raudhatul Mujawwidin pada mata pelajaran IPA materi bagian-bagian tumbuhan dan fungsinya memperoleh nilai $75 \%$ dari semua indikator minat belajar siswa atau dengan kriteria Cukup.

\section{B. PEMBAHASAN}

\section{Temuan Penelitian}

\section{a. Hasil Penelitian Pra Siklus}

Peneliti melakukan observasi pada tanggal 18 Juli 2018 selama dua jam pelajaran $(2 \times 35$ menit). Peneliti mengambil tempat untuk melakukan observasi dengan menggunakan lembar observasi yang telah dirancang. Pembelajaran IPA kelas IV disampaikan dengan menggunakan metode pembelajaran yang konvensional, dimana pembelajaran berorientasi pada guru (teacher centered approach) yaitu dengan penggunaan metode ceramah. Siswa belum berpartisipasi dengan baik dalam pembelajaran. Pembelajaran juga kurang memberikan pengalaman yang nyata terhadap siswa karena pembelajaran hanya terpaku pada buku paket saja. Kegiatan observasi dilakukan untuk mengamati minat belajar IPA siswa kelas IV MIS Raudhatul Mujawwidin dengan menggunakan lembaran observasi yang telah dirancang. Berikut adalah hasil observasi terhadap minat belajar siswa pada pembelajaran IPA pra siklus:

${ }^{14}$ Ibid. 
Tabel 3 Analisis Minat Belajar Siswa Pra Siklus

\begin{tabular}{|c|c|c|c|c|}
\hline $\begin{array}{l}\mathbf{N} \\
\mathbf{O}\end{array}$ & Indikator & Bentuk Tingkah Laku & $\begin{array}{c}\text { Persent } \\
\text { ase }\end{array}$ & $\begin{array}{c}\text { Ketercapai } \\
\text { an } \\
\end{array}$ \\
\hline \multirow{6}{*}{1} & \multirow{6}{*}{$\begin{array}{l}\text { Perhatian } \\
\text { siswa } \\
\text { dalam } \\
\text { kegiatan } \\
\text { belajar } \\
\text { mengajar }\end{array}$} & $\begin{array}{l}\text { Fokus memperhatikan penjelasan guru } \\
\text { dalam pembelajaran }\end{array}$ & $33,3 \%$ & \multirow{6}{*}{$45,78 \%$} \\
\hline & & Mencatat penjelasan guru & $55,5 \%$ & \\
\hline & & Membaca materi ajar & $55,5 \%$ & \\
\hline & & Serius dalam pelaksanaan tugas & $47,2 \%$ & \\
\hline & & Bersemangat mengerjakan tugas & $41,6 \%$ & \\
\hline & & $\begin{array}{l}\text { Tekun dan tidak mudah putus asa } \\
\text { dalam menyelesaikan tugas }\end{array}$ & $41,6 \%$ & \\
\hline \multirow{8}{*}{2} & \multirow{8}{*}{$\begin{array}{l}\text { Partisipasi } \\
\text { aktif siswa }\end{array}$} & Menjawab pertanyaan guru & $30,5 \%$ & \multirow{8}{*}{$36,075 \%$} \\
\hline & & Bertanya kepada guru & $25 \%$ & \\
\hline & & Mengemukakan pendapat & $27,7 \%$ & \\
\hline & & Aktif melakukan pengamatan & $50 \%$ & \\
\hline & & $\begin{array}{l}\text { Aktif mempresentasikan hasil } \\
\text { pengamatan }\end{array}$ & $41,6 \%$ & \\
\hline & & Menanggapi presentasi teman & $33,3 \%$ & \\
\hline & & Diskusi dengan anggota kelompoknya & $44,4 \%$ & \\
\hline & & Menyimpulkan hasil pembelajaran & $36,1 \%$ & \\
\hline \multirow{8}{*}{3} & \multirow{8}{*}{$\begin{array}{l}\text { Perasaan } \\
\text { senang } \\
\text { terhadap } \\
\text { kegiatan } \\
\text { belajar } \\
\text { mengajar }\end{array}$} & Masuk kelas tepat waktu & $69,4 \%$ & \multirow{8}{*}{$59,675 \%$} \\
\hline & & Membawa alat tulis dan buku & $83,3 \%$ & \\
\hline & & $\begin{array}{l}\text { Mempunyai catatan materi ajar yang } \\
\text { lengkap }\end{array}$ & $55,5 \%$ & \\
\hline & & Menyelesaikan tugas tepat waktu & $55,5 \%$ & \\
\hline & & Bertanggungjawab terhadap tugas & $55,5 \%$ & \\
\hline & & Tidak gelisah dalam belajar & $69,4 \%$ & \\
\hline & & $\begin{array}{l}\text { Tidak mudah bosan dan menyerah } \\
\text { dalam menyelesaikan tugas }\end{array}$ & $41,6 \%$ & \\
\hline & & Bersikap ceria & $47,2 \%$ & \\
\hline \multicolumn{4}{|c|}{ Jumlah } & 141,53 \\
\hline \multicolumn{4}{|c|}{ Rata-rata } & $47,17 \%$ \\
\hline
\end{tabular}

Berdasarkan tabel di atas, terlihat bahwa persentase minat belajar siswa pada mata pelajaran IPA pra siklus adalah sebesar $47,17 \%$, yang mana berada pada kriteria sangat kurang.

\section{b. Hasil Penelitian Tindakan Siklus I}

\section{i. Deskripsi Tindakan Siklus I Pertemuan 1}

Berdasarkan penelitian awal yang dilakukan pada pelaksanaan pembelajaran IPA di kelas IV MIS Raudhatul Mujawwidin, terdapat 
permasalahan yang perlu dikaji untuk dicarikan solusi permasalahannya, yaitu rendahnya minat siswa terhadap proses pembelajaran yang disebabkan pendekatan pembelajaran yang masih berpusat pada guru. Oleh karena itu, penerapan metode pembelajaran resitasi diperlukan guna mengatasi hal tersebut. Pelaksanaan penelitian pada siklus I pertemuan pertama dilakukan pada tanggal 23 Juli 2018 selama dua jam pelajaran $(2 \times 35$ menit) pada pukul 11.2512.35 WIB. Kegiatan pembelajaran dilaksanakan sesuai dengan RPP yang telah dibuat. Materi yang diajarkan adalah bagian akar tumbuhan. Berikut adalah analisis minat belajar siswa siklus I pertemuan 1:

Tabel 4 Analisis Minat Belajar Siklus I Pertemuan I

\begin{tabular}{|c|c|c|c|c|}
\hline No & Indikator & Bentuk Tingkah Laku & $\begin{array}{l}\text { Persent } \\
\text { ase }\end{array}$ & $\begin{array}{c}\text { Keterca } \\
\text { paian }\end{array}$ \\
\hline \multirow{6}{*}{1} & \multirow{6}{*}{$\begin{array}{c}\text { Perhatian } \\
\text { siswa dalam } \\
\text { kegiatan } \\
\text { belajar } \\
\text { mengajar }\end{array}$} & $\begin{array}{l}\text { Fokus memperhatikan penjelasan guru } \\
\text { dalam pembelajaran }\end{array}$ & $36,1 \%$ & \multirow{6}{*}{$49,96 \%$} \\
\hline & & Mencatat penjelasan guru & $72,2 \%$ & \\
\hline & & Membaca materi ajar & $55,5 \%$ & \\
\hline & & Serius dalam pelaksanaan tugas & $47,2 \%$ & \\
\hline & & Bersemangat mengerjakan tugas & $47,2 \%$ & \\
\hline & & $\begin{array}{l}\text { Tekun dan tidak mudah putus asa } \\
\text { dalam menyelesaikan tugas }\end{array}$ & $41,6 \%$ & \\
\hline \multirow{8}{*}{2} & \multirow{8}{*}{$\begin{array}{l}\text { Partisipasi } \\
\text { aktif siswa }\end{array}$} & Menjawab pertanyaan guru & $47,2 \%$ & \multirow{8}{*}{$43,7 \%$} \\
\hline & & Bertanya kepada guru & $33,3 \%$ & \\
\hline & & Mengemukakan pendapat & $38,8 \%$ & \\
\hline & & Aktif melakukan pengamatan & $55,5 \%$ & \\
\hline & & $\begin{array}{l}\text { Aktif mempresentasikan hasil } \\
\text { pengamatan }\end{array}$ & $47,2 \%$ & \\
\hline & & Menanggapi presentasi teman & $41,6 \%$ & \\
\hline & & Diskusi dengan anggota kelompoknya & $44,4 \%$ & \\
\hline & & Menyimpulkan hasil pembelajaran & $41,6 \%$ & \\
\hline \multirow{7}{*}{3} & \multirow{7}{*}{$\begin{array}{l}\text { Perasaan } \\
\text { senang } \\
\text { terhadap } \\
\text { kegiatan } \\
\text { belajar } \\
\text { mengajar }\end{array}$} & Masuk kelas tepat waktu & $58,3 \%$ & \multirow{7}{*}{$62,8 \%$} \\
\hline & & Membawa alat tulis dan buku & $83,3 \%$ & \\
\hline & & $\begin{array}{l}\text { Mempunyai catatan materi ajar yang } \\
\text { lengkap }\end{array}$ & $55,5 \%$ & \\
\hline & & Menyelesaikan tugas tepat waktu & $66,6 \%$ & \\
\hline & & Bertanggungjawab terhadap tugas & $69,4 \%$ & \\
\hline & & Tidak gelisah dalam belajar & $69,4 \%$ & \\
\hline & & $\begin{array}{l}\text { Tidak mudah bosan dan menyerah } \\
\text { dalam menyelesaikan tugas }\end{array}$ & $47,2 \%$ & \\
\hline
\end{tabular}




\begin{tabular}{|c|c|c|c|}
\hline & Bersikap ceria & $52,7 \%$ & \\
\hline \multicolumn{3}{|c|}{ Jumlah } & 156,46 \\
\hline Rata-rata & $52,15 \%$ \\
\hline
\end{tabular}

Berdasarkan tabel di atas, terlihat bahwa persentase minat belajar siswa pada mata pelajaran IPA sebesar 52,15\%, yang mana berada pada kriteria sangat kurang.

Berdasarkan hasil observasi selama pelaksanaan tindakan siklus I pertemuan 1, dapat diambil kesimpulan bahwa pembelajaran masih belum sesuai dengan aspek-aspek penilaian yang telah ditetapkan sebelumnya. Aspek-aspek tersebut yang belum terlaksana dengan baik dintaranya: a) Peneliti kurang menguasai kelas; b) Peneliti belum maksimal mengontrol siswa; c) Peneliti kurang optimal dalam memanfaatkan waktu; c) Peneliti kurang memberikan kesempatan kepada siswa lain untuk bertanya; d) Sebagian besar siswa terlihat kurang aktif dalam mengikuti pembelajaran; e) Siswa kurang fokus terhadap pembelajaran; f) Siswa masih kurang aktif bertanya; g) Minat belajar siswa belum mencapai target yakni 75\% dari masingmasing indikator.

Berdasarkan hasil refleksi di atas, maka perencanaan ulang yang peneliti lakukan yaitu penerapan metode resitasi dengan membawa objek yang dipelajari ke dalam kelas, serta membatasi lokasi pengamatan siswa dalam menyelesaikan tugas. Hal ini diharapkan dapat memudahkan guru dalam melakukan pengontrolan, serta menghemat waktu pembelajaran.

\section{ii. Deskripsi Tindakan Siklus I Pertemuan 2}

Berdasarkan hasil refleksi pada penelitian tindakan siklus I pertemuan 1, maka dilakukan tindakan pada siklus I pertemuan 2 . Peneliti menerapkan metode resitasi dengan membawa objek yang dipelajari sebagai upaya untuk perbaikan terhadap siklus I pertemuan pertama. Pelaksanaan penelitian pada siklus I pertemuan kedua dilakukan pada tanggal 24 Juli 2018 selama dua jam pelajaran $(2 \times 35$ menit) pada pukul 11.25-12.35 WIB. Kegiatan pembelajaran dilaksanakan sesuai dengan RPP yang telah dibuat. Materi yang 
diajarkan adalah batang tumbuhan. Berikut adalah analisis minat belajar siswa siklus I pertemuan 2:

Tabel 5 Analisis Minat Belajar Siklus I Pertemuan 2

\begin{tabular}{|c|c|c|c|c|}
\hline $\begin{array}{l}\mathrm{N} \\
\mathbf{O}\end{array}$ & Indikator & Bentuk Tingkah Laku & $\begin{array}{l}\text { Persenta } \\
\text { se }\end{array}$ & $\begin{array}{l}\text { Ketercap } \\
\text { aian }\end{array}$ \\
\hline \multirow{6}{*}{1} & \multirow{6}{*}{$\begin{array}{c}\text { Perhatian } \\
\text { siswa dalam } \\
\text { kegiatan } \\
\text { belajar } \\
\text { mengajar }\end{array}$} & $\begin{array}{l}\text { Fokus memperhatikan penjelasan guru } \\
\text { dalam pembelajaran }\end{array}$ & $52,7 \%$ & \multirow{6}{*}{$59,68 \%$} \\
\hline & & Mencatat penjelasan guru & $72,2 \%$ & \\
\hline & & Membaca materi ajar & $61,1 \%$ & \\
\hline & & Serius dalam pelaksanaan tugas & $55,5 \%$ & \\
\hline & & Bersemangat mengerjakan tugas & $55,5 \%$ & \\
\hline & & $\begin{array}{l}\text { Tekun dan tidak mudah putus asa } \\
\text { dalam menyelesaikan tugas }\end{array}$ & $61,1 \%$ & \\
\hline \multirow{8}{*}{2} & \multirow{8}{*}{$\begin{array}{l}\text { Partisipasi } \\
\text { aktif siswa }\end{array}$} & Menjawab pertanyaan guru & $61,1 \%$ & \multirow{8}{*}{$58,3 \%$} \\
\hline & & Bertanya kepada guru & $44,4 \%$ & \\
\hline & & Mengemukakan pendapat & $47,2 \%$ & \\
\hline & & Aktif melakukan pengamatan & $69,4 \%$ & \\
\hline & & $\begin{array}{l}\text { Aktif mempresentasikan hasil } \\
\text { pengamatan }\end{array}$ & $52,7 \%$ & \\
\hline & & Menanggapi presentasi teman & $61,1 \%$ & \\
\hline & & Diskusi dengan anggota kelompoknya & $61,1 \%$ & \\
\hline & & Menyimpulkan hasil pembelajaran & $69,4 \%$ & \\
\hline \multirow{8}{*}{3} & \multirow{8}{*}{$\begin{array}{l}\text { Perasaan } \\
\text { senang } \\
\text { terhadap } \\
\text { kegiatan } \\
\text { belajar } \\
\text { mengajar }\end{array}$} & Masuk kelas tepat waktu & $75 \%$ & \multirow{8}{*}{$69,075 \%$} \\
\hline & & Membawa alat tulis dan buku & $83,3 \%$ & \\
\hline & & $\begin{array}{l}\text { Mempunyai catatan materi ajar yang } \\
\text { lengkap }\end{array}$ & $61,1 \%$ & \\
\hline & & Menyelesaikan tugas tepat waktu & $72,2 \%$ & \\
\hline & & Bertanggungjawab terhadap tugas & $69,4 \%$ & \\
\hline & & Tidak gelisah dalam belajar & $75 \%$ & \\
\hline & & $\begin{array}{l}\text { Tidak mudah bosan dan menyerah } \\
\text { dalam menyelesaikan tugas }\end{array}$ & $55,5 \%$ & \\
\hline & & Bersikap ceria & $61,1 \%$ & \\
\hline \multicolumn{4}{|c|}{ Jumlah } & 187,055 \\
\hline \multicolumn{4}{|c|}{ Rata-rata } & $62,35 \%$ \\
\hline
\end{tabular}

Berdasarkan tabel di atas, minat belajar siswa pada siklus I pertemuan 2 ini adalah 62,35\% dengan kriteria kurang.

Berdasarkan hasil observasi tersebut, dapat diambil kesimpulan bahwa pembelajaran masih belum sesuai dengan aspek-aspek penilaian yang telah ditetapkan sebelumnya. Aspek-aspek tersebut yang belum terlaksana dengan baik dintaranya: a) Peneliti belum 
maksimal dalam mengelola kelas; b) Peneliti kurang optimal dalam memanfaatkan waktu; c) Peneliti kurang memberikan kesempatan kepada siswa lain untuk menanggapi pertanyaan dari siswa lain; d) Peneliti masih lemah dalam melakukan pengontrolan terhadap aktivitas siswa karena tidak semua siswa melakukan pengamatan di halaman kelas; d) Sebagian siswa terlihat kurang aktif dalam mengikuti pembelajaran; e) Siswa masih kurang aktif menanyakan hal-hal yang bersangkutan dengan materi; f) Minat belajar siswa belum mencapai target yakni $75 \%$ pada tiap-tiap indikator minat belajar.

Berdasarkan hasil refleksi di atas, maka perencanaan ulang yang peneliti lakukan yaitu penerapan metode resitasi dengan penambahan Lembar Kerja Siswa (LKS) serta membawa objek yang dipelajari ke dalam kelas sehingga siswa lebih cepat dalam menyelesaikan tugasnya.

\section{iii. Deskripsi Tindakan Siklus I Pertemuan 3}

Berdasarkan hasil refleksi pada penelitian tindakan siklus I pertemuan 2, maka dilakukan tindakan pada siklus I pertemuan 3 . Peneliti menerapkan metode resitasi dengan menambahkan LKS serta menghadirkan objek yang dipelajari ke dalam kelas, yaitu dengan membawa macam-macam daun. Pelaksanaan penelitian pada siklus I pertemuan ketiga dilakukan pada tanggal 25 Juli 2018 selama dua jam pelajaran ( $2 \times 35$ menit) pada pukul 11.25-12.35 WIB. Materi yang diajarkan adalah bagian-bagian daun tumbuhan. Berikut adalah tabel analisis minat belajar siswa siklus I pertemuan 3:

Tabel 6 Analisis Minat Belajar Siklus I Pertemuan 3

\begin{tabular}{|c|c|c|c|c|}
\hline $\begin{array}{l}\mathrm{N} \\
\mathrm{o}\end{array}$ & Indikator & Bentuk Tingkah Laku & Persentase & $\begin{array}{c}\text { Ketercap } \\
\text { aian }\end{array}$ \\
\hline \multirow{6}{*}{1} & \multirow{6}{*}{$\begin{array}{l}\text { Perhatian } \\
\text { siswa dalam } \\
\text { kegiatan } \\
\text { belajar } \\
\text { mengajar }\end{array}$} & $\begin{array}{l}\text { Fokus memperhatikan penjelasan } \\
\text { guru dalam pembelajaran }\end{array}$ & $63,8 \%$ & \multirow{6}{*}{$70,3 \%$} \\
\hline & & Mencatat penjelasan guru & $77,7 \%$ & \\
\hline & & Membaca materi ajar & $69,4 \%$ & \\
\hline & & Serius dalam pelaksanaan tugas & $63,8 \%$ & \\
\hline & & Bersemangat mengerjakan tugas & $69,4 \%$ & \\
\hline & & Tekun dan tidak mudah putus asa & $77,7 \%$ & \\
\hline
\end{tabular}




\begin{tabular}{|c|c|c|c|c|}
\hline \multirow{8}{*}{2} & \multirow{8}{*}{$\begin{array}{l}\text { Partisipasi } \\
\text { aktif siswa }\end{array}$} & Menjawab pertanyaan guru & $72,2 \%$ & \multirow{8}{*}{$71,125 \%$} \\
\hline & & Bertanya kepada guru & $58,3 \%$ & \\
\hline & & Mengemukakan pendapat & $66,6 \%$ & \\
\hline & & Aktif melakukan pengamatan & $77,7 \%$ & \\
\hline & & $\begin{array}{l}\text { Aktif mempresentasikan hasil } \\
\text { pengamatan }\end{array}$ & $63,8 \%$ & \\
\hline & & Menanggapi presentasi teman & $75 \%$ & \\
\hline & & $\begin{array}{l}\text { Diskusi dengan anggota } \\
\text { kelompoknya }\end{array}$ & $77,7 \%$ & \\
\hline & & Menyimpulkan hasil pembelajaran & $77,7 \%$ & \\
\hline \multirow{8}{*}{3} & \multirow{8}{*}{$\begin{array}{l}\text { Perasaan } \\
\text { senang } \\
\text { terhadap } \\
\text { kegiatan } \\
\text { belajar } \\
\text { mengajar }\end{array}$} & Masuk kelas tepat waktu & $77,7 \%$ & \multirow{8}{*}{$74,93 \%$} \\
\hline & & Membawa alat tulis dan buku & $86,1 \%$ & \\
\hline & & $\begin{array}{l}\text { Mempunyai catatan materi ajar } \\
\text { yang lengkap }\end{array}$ & $69,4 \%$ & \\
\hline & & Menyelesaikan tugas tepat waktu & $72,2 \%$ & \\
\hline & & Bertanggungjawab terhadap tugas & $72,2 \%$ & \\
\hline & & Tidak gelisah dalam belajar & $75 \%$ & \\
\hline & & Tidak mudah bosan dan menyerah & $66,6 \%$ & \\
\hline & & Bersikap ceria & $80,5 \%$ & \\
\hline \multicolumn{4}{|c|}{ Jumlah } & 216,355 \\
\hline \multicolumn{4}{|c|}{ Rata-rata } & $72,11 \%$ \\
\hline
\end{tabular}

Berdasarkan tabel diatas, diketahui bahwa minat belajar siswa mencapai nilai rata-rata 72,11\% dalam kategori cukup.

Berdasarkan hasil observasi selama pelaksanaan tindakan siklus I pertemuan 3, dapat diambil kesimpulan bahwa pembelajaran masih belum sesuai dengan aspek-aspek penilaian yang telah ditetapkan sebelumnya. Aspek-aspek tersebut yang belum terlaksana dengan baik diantaranya: a) Peneliti masih lemah dalam melakukan pengontrolan terhadap aktivitas siswa; b) Peneliti mulai efektif menggunakan waktu; c) Siswa mulai fokus terhadap pembelajaran; d) Siswa mulai aktif dalam mengikuti pembelajaran; e) Minat belajar siswa belum mencapai target yakni $75 \%$ pada masing-masing indikator minat belajar.

Berdasarkan hasil refleksi yang pada siklus I pertemuan 3 di atas, maka perencanaan ulang yang peneliti lakukan yaitu penerapan metode resitasi dengan menggunakan media gambar untuk memudahkan penyampaian materi serta menarik perhatian siswa. 
Selain itu, guru juga membawa objek yang dipelajari ke dalam kelas sehingga mempermudah siswa dalam menyelesaikan tugasnya.

\section{Deskripsi Tindakan Siklus II}

\section{i. Deskripsi Tindakan Siklus II Pertemuan 1}

Berdasarkan penelitian yang telah dilaksanakan pada siklus I yang dilakukan pada pelaksanaan pembelajaran IPA di kelas IV MIS Raudhatul Mujawwidin, terdapat hal-hal yang perlu diperbaiki untuk mengatasi permasalahan rendahnya minat siswa terhadap proses pembelajaran. Upaya yang peneliti lakukan adalah sebagai berikut: a) Membawa objek yang dipelajari ke dalam kelas sehingga mempermudah siswa dalam menyelesaikan tugasnya; b) Menambahkan penggunaan media gambar untuk mempermudah penyampaian materi serta menarik perhatian siswa.

Pelaksanaan penelitian pada siklus II pertemuan pertama dilakukan pada tanggal 30 Juli 2018 selama dua jam pelajaran $(2 \times 35$ menit) pada pukul 11.25-12.35 WIB. Materi yang diajarkan adalah bentuk-bentuk daun. Berikut adalah tabel analisis minat belajar siswa siklus II pertemuan 1:

Tabel 7 Analisis Minat Belajar Siklus II Pertemuan 1

\begin{tabular}{|c|c|c|c|c|}
\hline $\begin{array}{l}\mathrm{N} \\
\mathrm{o}\end{array}$ & Indikator & Bentuk Tingkah Laku & $\begin{array}{l}\text { Persent } \\
\text { ase }\end{array}$ & $\begin{array}{l}\text { Ketercap } \\
\text { aian }\end{array}$ \\
\hline \multirow{6}{*}{1} & \multirow{6}{*}{$\begin{array}{c}\text { Perhatian } \\
\text { siswa dalam } \\
\text { kegiatan } \\
\text { belajar } \\
\text { mengajar }\end{array}$} & $\begin{array}{l}\text { Fokus memperhatikan penjelasan guru } \\
\text { dalam pembelajaran }\end{array}$ & $75 \%$ & \multirow{6}{*}{$77,28 \%$} \\
\hline & & Mencatat penjelasan guru & $83,3 \%$ & \\
\hline & & Membaca materi ajar & $72,2 \%$ & \\
\hline & & Serius dalam pelaksanaan tugas & $75 \%$ & \\
\hline & & Bersemangat mengerjakan tugas & $80,5 \%$ & \\
\hline & & $\begin{array}{l}\text { Tekun dan tidak mudah putus asa dalam } \\
\text { menyelesaikan tugas }\end{array}$ & $77,7 \%$ & \\
\hline \multirow{7}{*}{2} & \multirow{7}{*}{$\begin{array}{l}\text { Partisipasi } \\
\text { aktif siswa }\end{array}$} & Menjawab pertanyaan guru & $75 \%$ & \multirow{7}{*}{$73,57 \%$} \\
\hline & & Bertanya kepada guru & $58,3 \%$ & \\
\hline & & Mengemukakan pendapat & $69,4 \%$ & \\
\hline & & Aktif melakukan pengamatan & $83,3 \%$ & \\
\hline & & $\begin{array}{l}\text { Aktif mempresentasikan hasil } \\
\text { pengamatan }\end{array}$ & $66,6 \%$ & \\
\hline & & Menanggapi presentasi teman & $75 \%$ & \\
\hline & & Diskusi dengan anggota kelompoknya & $83,3 \%$ & \\
\hline
\end{tabular}




\begin{tabular}{|c|c|c|c|c|}
\hline & & Menyimpulkan hasil pembelajaran & $77,7 \%$ & \\
\hline \multirow{8}{*}{3} & \multirow{8}{*}{$\begin{array}{l}\text { Perasaan } \\
\text { senang } \\
\text { terhadap } \\
\text { kegiatan } \\
\text { belajar } \\
\text { mengajar }\end{array}$} & Masuk kelas tepat waktu & $83,3 \%$ & \multirow{8}{*}{$80,86 \%$} \\
\hline & & Membawa alat tulis dan buku & $91,6 \%$ & \\
\hline & & $\begin{array}{l}\text { Mempunyai catatan materi ajar yang } \\
\text { lengkap }\end{array}$ & $80,5 \%$ & \\
\hline & & Menyelesaikan tugas tepat waktu & $75 \%$ & \\
\hline & & Bertanggungjawab terhadap tugas & $75 \%$ & \\
\hline & & Tidak gelisah dalam belajar & $75 \%$ & \\
\hline & & $\begin{array}{l}\text { Tidak mudah bosan dan menyerah dalam } \\
\text { menyelesaikan tugas }\end{array}$ & $77,7 \%$ & \\
\hline & & Bersikap ceria & $88,8 \%$ & \\
\hline \multicolumn{4}{|c|}{ Jumlah } & 231,71 \\
\hline \multicolumn{4}{|c|}{ Rata-rata } & $77,23 \%$ \\
\hline
\end{tabular}

Berdasarkan tabel diatas, diketahui bahwa minat belajar siswa pada siklus II pertemuan 1 ini mencapai nilai rata-rata 77,23\% dalam kategori cukup. Namun, penelitian ini belum dikatakan berhasil karena pada indikator partisipasi aktif siswa belum mencapai kriteria keberhasilan tindakan seperti yang telah ditetapkan sebelumnya, yaitu sebesar $75 \%$.

Berdasarkan hasil observasi selama pelaksanaan tindakan siklus II pertemuan 1 menunjukkan perubahan pada beberapa aspek yang kurang maksimal pada pelaksanaan tindakan siklus I. Perubahan tersebut diuraikan sebagai berikut: a) Peneliti mulai bisa menarik perhatian siswa; b) Peneliti terlihat sudah mulai bisa memfokuskan perhatian siswa, mengkondisikan kelas dan mempersiapkan siswa untuk belajar; c) Siswa mulai aktif bertanya serta aktif berinteraksi dengan anggota kelompok lainnya; d) Indikator partisipasi aktif siswa belum mencapai target yang telah ditetapkan sebelumnya, yakni 75\%. Berdasarkan hasil refleksi serta hasil observasi terhadap minat belajar siswa di atas, dapat diketahui bahwa minat belajar siswa mengalami peningkatan yang cukup signifikan. Perencanaan ulang yang peneliti lakukan yaitu penerapan metode resitasi dengan penggunakan media gambar untuk memperjelas penyampaian materi serta menarik perhatian siswa terhadap materi yang diajarkan. Selain itu, peneliti juga membawa objek yang dipelajari ke dalam kelas sehingga siswa dapat dengan mudah melakukan pengamatan serta memudahkan guru dalam melakukan pengontrolan. 


\section{ii. Deskripsi Tindakan Siklus II Pertemuan 2}

Berdasarkan penelitian yang telah dilaksanakan pada siklus II pertemuan 1, terdapat hal-hal yang perlu ditingkatkan. Upaya yang peneliti lakukan adalah menambahkan penggunaan media gambar untuk mempermudah dan memperjelas penyampaian materi ajar. Pelaksanaan penelitian pada siklus II pertemuan kedua dilakukan pada tanggal 1 Agustus 2018 selama dua jam pelajaran $(2 \times 35$ menit) pada pukul 11.25-12.35 WIB. Materi yang diajarkan adalah bagian bunga tumbuhan. Berikut adalah tabel analisis minat belajar siswa siklus II pertemuan 2:

Tabel 8 Analisis Minat Belajar Siklus II Pertemuan 2

\begin{tabular}{|c|c|c|c|c|}
\hline $\begin{array}{l}N \\
0\end{array}$ & Indikator & Bentuk Tingkah Laku & $\begin{array}{c}\text { Persent } \\
\text { ase }\end{array}$ & $\begin{array}{c}\text { Ketercap } \\
\text { aian }\end{array}$ \\
\hline \multirow{6}{*}{1} & \multirow{6}{*}{$\begin{array}{l}\text { Perhatian } \\
\text { siswa dalam } \\
\text { kegiatan } \\
\text { belajar } \\
\text { mengajar }\end{array}$} & $\begin{array}{l}\text { Fokus memperhatikan penjelasan guru } \\
\text { dalam pembelajaran }\end{array}$ & $77,7 \%$ & \multirow{6}{*}{$81,41 \%$} \\
\hline & & Mencatat penjelasan guru & $88,8 \%$ & \\
\hline & & Membaca materi ajar & $77,7 \%$ & \\
\hline & & Serius dalam pelaksanaan tugas & $80,5 \%$ & \\
\hline & & Bersemangat mengerjakan tugas & $83,3 \%$ & \\
\hline & & $\begin{array}{l}\text { Tekun dan tidak mudah putus asa } \\
\text { dalam menyelesaikan tugas }\end{array}$ & $80,5 \%$ & \\
\hline \multirow{8}{*}{2} & \multirow{8}{*}{$\begin{array}{l}\text { Partisipasi } \\
\text { aktif siswa }\end{array}$} & Menjawab pertanyaan guru & $77,7 \%$ & \multirow{8}{*}{$76,68 \%$} \\
\hline & & Bertanya kepa da guru & $69,4 \%$ & \\
\hline & & Mengemukakan pendapat & $61,1 \%$ & \\
\hline & & Aktif melakukan pengamatan & $88,8 \%$ & \\
\hline & & $\begin{array}{l}\text { Aktif mempresentasikan hasil } \\
\text { pengamatan }\end{array}$ & $75 \%$ & \\
\hline & & Menanggapi presentasi teman & $77,7 \%$ & \\
\hline & & Diskusi dengan anggota kelompoknya & $86,1 \%$ & \\
\hline & & Menyimpulkan hasil pembelajaran & $77,7 \%$ & \\
\hline \multirow{8}{*}{3} & \multirow{8}{*}{$\begin{array}{l}\text { Perasaan } \\
\text { senang } \\
\text { terhadap } \\
\text { kegiatan } \\
\text { belajar } \\
\text { mengajar }\end{array}$} & Masuk kelas tepat waktu & $88,8 \%$ & \multirow{8}{*}{$85,71 \%$} \\
\hline & & Membawa alat tulis dan buku & $91,6 \%$ & \\
\hline & & $\begin{array}{l}\text { Mempunyai catatan materi ajar yang } \\
\text { lengkap }\end{array}$ & $86,1 \%$ & \\
\hline & & Menyelesaikan tugas tepat waktu & $83,3 \%$ & \\
\hline & & Bertanggungjawab terhadap tugas & $80,5 \%$ & \\
\hline & & Tidak gelisah dalam belajar & $80,5 \%$ & \\
\hline & & $\begin{array}{l}\text { Tidak mudah bosan dan menyerah } \\
\text { dalam menyelesaikan tugas }\end{array}$ & $83,3 \%$ & \\
\hline & & Bersikap ceria & $91.6 \%$ & \\
\hline
\end{tabular}




\begin{tabular}{|c|c|}
\hline Jumlah & 243,8 \\
\hline Rata-rata & $81,26 \%$ \\
\hline
\end{tabular}

Berdasarkan tabel diatas, diketahui bahwa minat belajar siswa pada siklus II pertemuan 2 ini mencapai nilai rata-rata $81,26 \%$ dalam kategori baik. Masing-masing indikator minat belajar siswa telah mencapai $75 \%$.

Berdasarkan hasil observasi selama pelaksanaan tindakan siklus II pertemuan 2 menunjukkan perubahan pada beberapa aspek yang kurang maksimal pada pelaksanaan tindakan siklus II pertemuan 1 . Perubahan tersebut diuraikan sebagai berikut: a) Peneliti bisa menarik perhatian siswa; b) Peneliti terlihat sudah bisa mengkondisikan kelas dan mempersiapkan siswa untuk belajar; c) Siswa aktif bertanya; d) Siswa aktif berdiskusi dan melakukan pengamatan; e) Siswa aktif mempresentasikan hasil pengamatan; f) Minat belajar siswa telah mencapai target, yakni $75 \%$ pada masing-masing indikator. Berdasarkan hasil refleksi yang dilakukan pada siklus II pertemuan 2 di atas, minat belajar siswa telah mencapai 82,54\%. Hal ini menunjukkan minat belajar siswa telah mencapai target yang ditetapkan sebelumnya, yakni $75 \%$ pada masing-masing indikator. Berdasarkan data tersebut, dapat disimpulkan bahwa penggunaan metode resitasi yang dipadukan dengan media gambar pada materi bagian-bagian tumbuhan dan fungsinya dapat meningkatkan minat belajar siswa. Oleh sebab itu, penelitian pada siklus II ini dikatakan berhasil sehingga penelitian tindakan dihentikan dan tidak dilanjutkan pada siklus selanjutnya.

b. Hasil Observasi Minat Belajar Siswa

Peningkatan minat belajar siswa pada masing-masing siklus dapat dilihat pada tabel berikut ini:

Tabel 9 Peningkatan Minat Belajar Siswa Pra Siklus,

Siklus I dan Siklus II

\begin{tabular}{|c|l|c|c|c|c|c|c|}
\hline \multirow{2}{*}{ No } & \multirow{2}{*}{$\begin{array}{l}\text { Indikator Minat } \\
\text { Belajar }\end{array}$} & \multirow{2}{*}{$\begin{array}{c}\text { Pra } \\
\text { Siklus }\end{array}$} & \multicolumn{3}{|c|}{ Siklus I } & \multicolumn{2}{|c|}{ Siklus II } \\
\cline { 6 - 8 } & & P. 1 & P. 2 & P. 3 & P. 1 & P. 2 \\
\hline 1 & Perhatian Siswa & $45,78 \%$ & $49,96 \%$ & $59,68 \%$ & $70,3 \%$ & $77,28 \%$ & $81,41 \%$ \\
\hline 2 & $\begin{array}{l}\text { Partisipasi } \\
\text { Aktif Siswa }\end{array}$ & $36,075 \%$ & $43,7 \%$ & $58,3 \%$ & $71,125 \%$ & $73,57 \%$ & $76,68 \%$ \\
\hline 3 & Perasaan & $59,675 \%$ & $62,8 \%$ & $69,075 \%$ & $74,93 \%$ & $80,86 \%$ & $85,71 \%$ \\
\hline
\end{tabular}


Mulyati, Mona Novita

\begin{tabular}{|c|c|c|c|c|c|c|}
\hline Senang & & & & & & \\
\hline $\begin{array}{c}\text { Rata-rata Per } \\
\text { Pertemuan }\end{array}$ & $47,17 \%$ & $52,15 \%$ & $62,35 \%$ & $72,11 \%$ & $77,23 \%$ & $81,26 \%$ \\
\hline Rata-rata Per Siklus & $47,17 \%$ & \multicolumn{3}{|c|}{$62,20 \%$} & $79,24 \%$ \\
\hline
\end{tabular}

Masing-masing indikator minat belajar terbagi menjadi bentukbentuk tingkah laku yang diamati. Secara rinci, peningkatan indikator perhatian siswa terhadap pembelajaran pada pra siklus, siklus I dan siklus II adalah sebagai berikut:

Tabel 10 Peningkatan Perhatian Siswa

\begin{tabular}{|c|c|c|c|c|c|c|c|c|}
\hline \multirow{2}{*}{ No } & \multirow{2}{*}{$\begin{array}{c}\text { Bentuk Tingkah } \\
\text { laku }\end{array}$} & \multirow{2}{*}{$\begin{array}{l}\text { Pra } \\
\text { Siklus }\end{array}$} & \multicolumn{3}{|c|}{ Siklus I } & \multicolumn{2}{|c|}{ Siklus II } & \multirow{2}{*}{$\begin{array}{l}\text { Rata- } \\
\text { rata }\end{array}$} \\
\hline & & & P. 1 & P. 2 & P. 3 & P.1 & P. 2 & \\
\hline 1 & $\begin{array}{l}\text { Fokus } \\
\text { memperhatikan } \\
\text { penjelasan }\end{array}$ & $33,3 \%$ & $36,1 \%$ & $52,7 \%$ & $63,8 \%$ & $75 \%$ & $77,7 \%$ & $56,43 \%$ \\
\hline 2 & $\begin{array}{l}\text { Mencatat } \\
\text { penjelasan }\end{array}$ & $55,5 \%$ & $72,2 \%$ & $72,2 \%$ & $77,7 \%$ & $83,3 \%$ & $88,8 \%$ & $74,95 \%$ \\
\hline 3 & $\begin{array}{l}\text { Membaca materi } \\
\text { ajar }\end{array}$ & $55,5 \%$ & $55,5 \%$ & $61,1 \%$ & $69,4 \%$ & $72,2 \%$ & $77,7 \%$ & $65,23 \%$ \\
\hline 4 & $\begin{array}{ll}\text { Serius } & \text { dalam } \\
\text { tugas } & \end{array}$ & $47,2 \%$ & $47,2 \%$ & $55,5 \%$ & $63,8 \%$ & $75 \%$ & $80,5 \%$ & $61,53 \%$ \\
\hline 5 & $\begin{array}{l}\text { Bersemangat } \\
\text { mengerjakan } \\
\text { tugas }\end{array}$ & $41,6 \%$ & $47,2 \%$ & $55,5 \%$ & $69,4 \%$ & $80,3 \%$ & $83,3 \%$ & $62,88 \%$ \\
\hline 6 & $\begin{array}{l}\text { Tekun \& tidak } \\
\text { putus asa }\end{array}$ & $41,6 \%$ & $41,6 \%$ & $61,1 \%$ & $77,7 \%$ & $77,7 \%$ & $75 \%$ & $63,36 \%$ \\
\hline
\end{tabular}

Indikator minat belajar yang kedua yaitu partisipasi aktif siswa. Peningkatan partisipasi siswa dalam pembelajaran pra siklus, siklus I dan siklus II dapat dilihat pada tabel berikut:

Tabel 11 Peningkatan Partisipasi Siswa

\begin{tabular}{|c|c|c|c|c|c|c|c|c|}
\hline \multirow{2}{*}{$\begin{array}{l}\mathrm{N} \\
\mathrm{O}\end{array}$} & \multirow{2}{*}{ Bentuk Tingkah Laku } & \multirow{2}{*}{$\begin{array}{c}\text { Pra } \\
\text { Siklus }\end{array}$} & \multicolumn{3}{|c|}{ Siklus I } & \multicolumn{2}{|c|}{ Siklus II } & \multirow{2}{*}{$\begin{array}{l}\text { Rata } \\
\text {-rata }\end{array}$} \\
\hline & & & P. 1 & P. 2 & P. 3 & P. 1 & P. 2 & \\
\hline 1 & $\begin{array}{l}\text { Menjawab } \\
\text { pertanyaan guru }\end{array}$ & $30,5 \%$ & $\begin{array}{c}47,2 \\
\%\end{array}$ & $\begin{array}{c}61,1 \\
\%\end{array}$ & $\begin{array}{c}72,2 \\
\%\end{array}$ & $75 \%$ & $\begin{array}{c}77,7 \\
\%\end{array}$ & $\begin{array}{c}60,6 \\
1 \%\end{array}$ \\
\hline 2 & Bertanya kepada guru & $25 \%$ & $\begin{array}{c}33,3 \\
\%\end{array}$ & $\begin{array}{c}44,4 \\
\%\end{array}$ & $\begin{array}{c}58,3 \\
\%\end{array}$ & $\begin{array}{c}58,3 \\
\%\end{array}$ & $\begin{array}{c}69,4 \\
\%\end{array}$ & $\begin{array}{c}48,1 \\
1 \%\end{array}$ \\
\hline 3 & $\begin{array}{l}\text { Mengemukakan } \\
\text { pendapat }\end{array}$ & $27,7 \%$ & $\begin{array}{c}38,5 \\
\%\end{array}$ & $\begin{array}{c}47,2 \\
\%\end{array}$ & $\begin{array}{c}66.6 \\
\%\end{array}$ & $\begin{array}{c}69,4 \\
\%\end{array}$ & $\begin{array}{c}61,1 \\
\%\end{array}$ & $\begin{array}{c}51,8 \\
\%\end{array}$ \\
\hline 4 & $\begin{array}{l}\text { Aktif melakukan } \\
\text { pengamatan }\end{array}$ & $50 \%$ & $\begin{array}{c}55,5 \\
\%\end{array}$ & $\begin{array}{c}69,4 \\
\%\end{array}$ & $\begin{array}{c}77,7 \\
\%\end{array}$ & $\begin{array}{c}83,3 \\
\%\end{array}$ & $\begin{array}{c}88,8 \\
\%\end{array}$ & $\begin{array}{c}70,7 \\
8 \%\end{array}$ \\
\hline 5 & Aktif & $41,6 \%$ & 47,2 & 52,7 & 63,8 & 66,6 & $75 \%$ & 57,8 \\
\hline
\end{tabular}


Meningkatkan Minat Belajar ...

\begin{tabular}{|c|l|c|c|c|c|c|c|c|}
\hline & $\begin{array}{l}\text { mempresentasikan } \\
\text { hasil pengamatan }\end{array}$ & $\%$ & $\%$ & $\%$ & $\%$ & & $1 \%$ \\
\hline 6 & $\begin{array}{l}\text { Menanggapi } \\
\text { presentasi teman }\end{array}$ & $33,3 \%$ & $\begin{array}{c}41,6 \\
\%\end{array}$ & $\begin{array}{c}61,1 \\
\%\end{array}$ & $75 \%$ & $75 \%$ & $\begin{array}{c}77,7 \\
\%\end{array}$ & $\begin{array}{c}60,6 \\
1 \%\end{array}$ \\
\hline 7 & $\begin{array}{l}\text { Diskusi dengan } \\
\text { anggota } \\
\text { kelompoknya }\end{array}$ & $44,4 \%$ & $\begin{array}{c}44,4 \\
\%\end{array}$ & $\begin{array}{c}61,1 \\
\%\end{array}$ & $\begin{array}{c}77,7 \\
\%\end{array}$ & $\begin{array}{c}83,3 \\
\%\end{array}$ & $\begin{array}{c}86,1 \\
\%\end{array}$ & $\begin{array}{c}66,1 \\
6 \%\end{array}$ \\
\hline 8 & $\begin{array}{l}\text { Menyimpulkan hasil } \\
\text { pembelajaran }\end{array}$ & $36,1 \%$ & $\begin{array}{c}41,6 \\
\%\end{array}$ & $\begin{array}{c}69,4 \\
\%\end{array}$ & $\begin{array}{c}77,7 \\
\%\end{array}$ & $\begin{array}{c}77,7 \\
\%\end{array}$ & $\begin{array}{c}77,7 \\
\%\end{array}$ & $\begin{array}{c}63,3 \\
6 \%\end{array}$ \\
\hline
\end{tabular}

Perasaan senang siswa terhadap kegiatan belajar mengajar merupakan indikator minat belajar. Peningkatan perasaan senang siswa dalam pembelajaran pra siklus, siklus I dan siklus II dapat dilihat pada tabel berikut:

\section{Tabel 12 Peningkatan Perasaan Senang Siswa}

\begin{tabular}{|c|c|c|c|c|c|c|c|c|}
\hline \multirow{2}{*}{ No } & \multirow{2}{*}{$\begin{array}{c}\text { Bentuk } \\
\text { Tingkah Laku }\end{array}$} & \multirow{2}{*}{$\begin{array}{l}\text { Pra } \\
\text { Siklus }\end{array}$} & \multicolumn{3}{|c|}{ Siklus I } & \multicolumn{2}{|c|}{ Siklus II } & \multirow{2}{*}{ Rata-rata } \\
\hline & & & P. 1 & P. 2 & P. 3 & P. 1 & P. 2 & \\
\hline 1 & $\begin{array}{l}\text { Masuk kelas } \\
\text { tepat waktu }\end{array}$ & $69,4 \%$ & $58,3 \%$ & $75 \%$ & $77,7 \%$ & $83,3 \%$ & $88,8 \%$ & $75,41 \%$ \\
\hline 2 & $\begin{array}{l}\text { Membawa alat } \\
\text { tulis dan buku }\end{array}$ & $83,3 \%$ & $83,3 \%$ & $83,3 \%$ & $86,1 \%$ & $91,6 \%$ & $91,6 \%$ & $86,53 \%$ \\
\hline 3 & \begin{tabular}{lr}
\multicolumn{3}{l}{ Mempunyai } \\
catatan materi \\
ajar yang \\
lengkap
\end{tabular} & $55,5 \%$ & $55,5 \%$ & $61,1 \%$ & $69,4 \%$ & $80,5 \%$ & $86,1 \%$ & $68,01 \%$ \\
\hline 4 & $\begin{array}{l}\text { Menyelesaika } \\
\mathrm{n} \text { tugas tepat } \\
\text { waktu }\end{array}$ & $55,5 \%$ & $66,6 \%$ & $72,2 \%$ & $72,2 \%$ & $75 \%$ & $83,3 \%$ & $70,8 \%$ \\
\hline 5 & $\begin{array}{l}\text { Bertanggungj } \\
\text { awab } \\
\text { terhadap } \\
\text { tugas }\end{array}$ & $55,5 \%$ & $69,4 \%$ & $69,4 \%$ & $72,2 \%$ & $75 \%$ & $80,5 \%$ & $70,33 \%$ \\
\hline 6 & $\begin{array}{l}\text { Tidak gelisah } \\
\text { dalam belajar }\end{array}$ & $69,4 \%$ & $69,4 \%$ & $75 \%$ & $75 \%$ & $75 \%$ & $80,5 \%$ & $74,05 \%$ \\
\hline 7 & $\begin{array}{l}\text { Tidak mudah } \\
\text { bosan dan } \\
\text { menyerah }\end{array}$ & $41,6 \%$ & $47,2 \%$ & $55,5 \%$ & $66,6 \%$ & $77,7 \%$ & $83,3 \%$ & $61,98 \%$ \\
\hline 8 & Bersikap ceria & $47,2 \%$ & $52,7 \%$ & $61,1 \%$ & $80,3 \%$ & $88,8 \%$ & $91,6 \%$ & $70,28 \%$ \\
\hline
\end{tabular}




\section{Pembahasan}

Berdasarkan tindakan yang telah dilaksanakan pada siklus I dan II dengan penerapan metode resitasi untuk meningkatkan minat belajar siswa kelas IV MIS Raudhatul Mujawwidin pada mata pelajaran IPA materi bagian-bagian tumbuhan dan fungsinya, maka penelitian ini dikatakan berhasil karena telah mencapai indikator keberhasilan tindakan yang telah ditetapkan yaitu memperoleh nilai $75 \%$ pada semua indikator minat belajar siswa.

\section{c. Perhatian Siswa dalam Kegiatan Belajar Mengajar}

Berdasarkan tabel 10, bentuk tingkah laku yang mendapat persentase paling tinggi adalah mencatat penjelasan guru yaitu 74,95\%. Hal tersebut menandakan siswa telah memiliki perhatian terhadap pembelajaran. Selanjutnya, bentuk tingkah laku membaca materi ajar mendapat persentase $65,23 \%$. Hal tersebut sesuai dengan kelebihan metode resitasi. Menurut Jamil, salah satu kelebihan metode pembelajaran resitasi adalah merangsang siswa dalam melakukan aktivitas belajar individu dan kelompok. ${ }^{15}$ Aspek yang mendapat persentase paling rendah adalah fokus memperhatikan penjelasan guru, yaitu 56,43\%. Sesuai dengan kelemahan metode resitasi, guru sulit melakukan pengontrolan terhadap siswa. Sehingga hal tersebut mempengaruhi fokus siswa terhadap pembelajaran.

\section{d. Partisipasi Aktif Siswa}

Berdasarkan tabel 11, bentuk tingkah laku yang paling tinggi persentasenya adalah aktif melakukan pengamatan, yaitu 70,78\%. Hal ini sesuai dengan kelebihan metode resitasi. Metode resitasi ini dapat merangsang siswa untuk belajar lebih aktif, baik secara perorangan maupun kelompok, menumbuhkan kebiasaan untuk belajar mencari dan menemukan, mengembangkan keberanian dan tanggung jawab terhadap diri sendiri dan memungkinkan untuk memperoleh hasil yang permanen. ${ }^{16}$ Sedangkan yang paling rendah persentasenya adalah partisipasi aktif siswa dalam bertanya kepada guru, yaitu

${ }^{15}$ Jamil Suprihatiningrum, Strategi Pembelajaran: Teori \& Aplikasi (Jogjakarta: Ar Ruzz Media, 2013), h. 292-293

${ }^{16}$ Ibid., h. 209 
48,11\%. Hal tersebut sesuai dengan kelemahan metode resitasi, yaitu guru sulit membedakan siswa yang aktif dan pasif jika tugas dikerjakan secara berkelompok. ${ }^{17}$ Karena pada saat pembelajaran, pendapat atau pertanyaan dari suatu kelompok hanya disampaikan oleh perwakilan kelompok saja.

e. Perasaan Senang terhadap Kegiatan Belajar Mengajar

Berdasarkan tabel 12, bentuk tingkah laku yang paling tinggi persentasenya adalah membawa alat tulis dan buku, yaitu 86,53\%. Selanjutnya, masuk kelas tepat waktu dengan persentase $75,41 \%$. Hal tersebut sesuai dengan salah satu kelebihan metode resitasi, yaitu dapat meningkatkan kemandirian, tanggung jawab, disiplin, kreativitas, dan kerja sama siswa di luar pengawasan guru. ${ }^{18}$ Seperti yang diungkapkan oleh R.S. Chauhan, belajar membawa perubahanperubahan dalam tingkah laku dari organisme, ${ }^{19}$ maka aktivitasaktivitas tersebut menjadi penanda bahwa siswa telah mengalami proses belajar serta menyenangi proses pembelajaran. Bentuk tingkah laku yang paling rendah persentasenya adalah tidak mudah bosan dan menyerah dalam belajar, yaitu 61,98\%. Dalam proses pengamatan, guru sulit mengamati tanggung jawab siswa terhadap tugas yang diberikan. Hal tersebut sesuai dengan kelemahan metode resitasi, yaitu guru tidak dapat mengontrol apakah siswa telah mengerjakan tugas dengan benar, serta sulit membedakan siswa yang aktif dan pasif jika tugas dikerjakan secara berkelompok. ${ }^{20}$

\section{PENUTUP}

Berdasarkan hasil penelitian dan pembahasan pada bab sebelumnya, penelitian tindakan kelas yang dilakukan di Madrasah Ibtidaiyah Swasta (MIS) Raudhatul Mujawwidin Kecamatan Rimbo Bujang Kabupaten Tebo dapat disimpulkan sebagai berikut:

${ }^{17}$ Ibid., h. 293

${ }^{18}$ Ibid., h. 292

${ }^{19}$ Purwa Atmaja Prawira, Psikologi Pendidikan dalam Perspektif Baru (Jogjakarta: Ar-Ruzz Media, 2014), h. 227

${ }^{20}$ Suprihatiningrum, Strategi Pembelajaran, h. 293 
1. Minat belajar siswa pada pembelajaran IPA di kelas IV MIS Raudhatul Mujawwidin Kecamatan Rimbo Bujang kabupaten Tebo dengan penerapan metode resitasi mengalami peningkatan. Hal ini terlihat dalam hasil penelitian yang menunjukkan minat belajar siswa telah mencapai indikator keberhasilan penelitian yaitu $75 \%$ pada setiap indikator minat belajar siswa. Rata-rata minat belajar siswa pada pra siklus adalah $47,17 \%$. Pada siklus I, rata-rata minat belajar siswa adalah $62,20 \%$ atau pada kriteria kurang dan pada siklus II yaitu 79,24\% atau pada kriteria cukup.

2. Indikator yang mengalami peningkatan yang cukup signifikan pada mata pelajaran IPA dengan penerapan metode resitasi adalah indikator perasaan senang siswa terhadap pembelajaran. Rata-rata perasaan senang siswa terhadap kegiatan belajar mengajar pada pra siklus adalah 59,67\%. Pada siklus I, perasaan senang siswa terhadap pembelajaran adalah $68,93 \%$, dan meningkat mencapai $83,28 \%$ pada siklus II.

\section{Daftar Pustaka}

Abdul Majid. Strategi Pembelajaran. Bandung: Remaja Rosdakarya, 2014.

Baharuddin dan Esa Nur Wahyuni. Teori Belajar \& Pembelajaran. Yogyakarta, Ar-Ruzz Media, 2015.

Ferry Sulistiyono. "Peningkatan Minat Belajar Siswa Terhadap Pembelajaran Tematik Kelas I Melalui Metode Story Telling di SD N Gembongan Sentolo Kulon Progo" (Skripsi, FIP Universitas Negeri Yogyakarta, 2014).

H. Cholil dan Sugeng Kurniawan. Psikologi Pendidikan: Telaah Teoritik dan Praktik. Surabaya: IAIN Sunan Ampel Press, 2011.

Isriani Hardini dan Dewi Puspitasari, Strategi Pembelajaran Terpadu: Teori, Konsep, \& Implementasi. Yogyakarta: Familia, 2012.

Jamil Suprihatiningrum. Strategi Pembelajaran: Teori \& Aplikasi. Jogjakarta: Ar Ruzz Media, 2013. 
Meningkatkan Minat Belajar ...

Jumanta Hamdayama. Metodologi Pengajaran. Jakarta: PT Bumi aksara, 2016.

Khanifatul. Pembelajaran Inovatif: Strategi Mengolah Kelas Secara Efektif dan Menyenangkan. Jogjakarta: Ar-Ruzz Media, 2014.

Moh Haitami Salim dan Syamsul Kurniawan. Studi Ilmu Pendidikan Islam. Yogyakarta: Ar-Ruzz Media, 2012.

Muhammad Fathurrohman. Model-model Pembelajaran Inovatif: Alternatif Desain Pembelajaran yang Menyenangkan. Jogjakarta: Ar Ruzz Media, 2015.

Muhammad Yaumi. Prinsip-prinsip Desain Pembelajaran disesuaikan dengan Kurikulum 2013. Jakarta: Kencana, 2017.

Ngainun Naim. Dasar-dasar Komunikasi Pendidikan. Jogjakarta: ArRuzz Media, 2011.

Novan Ardy Wiyani. Desain Pembelajaran Pendidikan: Tata Rancang Pembelajaran Menuju Pencapaian Kompetensi. Yogyakarta: ArRuzz Media, 2013.

Nur Khalida Prettiana. "Peningkatan Minat Belajar IPA Melalui Model Pembelajaran Kooperatif Tipe STAD (Student Teams Achievement Divisions) pada Siswa Kelas V SD N 1 Sedayu Bantul” (Skripsi, FIP Universitas Negeri Yogyakarta, 2016).

Permendiknas RI No. 22 Tahun 2006. Standar Isi Satuan Pendidikan Dasar Menengah.

https://www.scribd.com/mobile/doc/48620155/lampiranpermendikas-nomor-22-tahun-2006tentang-standar-isilampiran-SD-MI

Purwa Atmaja Prawira. Psikologi Pendidikan dalam Perspektif Baru. Jogjakarta: Ar-Ruzz Media, 2014.

R. Hidayah. “Bab III Metode Penelitian.” Repo.iain-tulungagung.ac.id.

Syaiful Bahri Djamarah dan Aswan Zain. Strategi Belajar Mengajar. Jakarta: Rineka Cipta, 2013. 
Trianto. Desain Pengembangan Pembelajaran Tematik Bagi Anak Usia Dini TK/RA \& Anak Kelas Awal SD/MI. Jakarta: Kencana, 2011

Ujang Erianto. “Upaya Meningkatkan Minat Belajar Siswa dengan Menggunakan Media Gambar dalam Pembelajaran IPA di Kelas IV SD Krapyak Wetan" (Skripsi, $\quad$ FIP Universitas Negeri Yogyakarta, 2016). 